\title{
2台のH-ADCP計測とDIEX法に基づく 複断面河道の洪水流量計測 ～台風1112号出水を例に〜 A RIVER-DISCHARGE MONITORING IN A COMPOUND CHANNEL WITH MEASUREMENTS OF TWO H-ADCPS AND COMPUTATION BY DIEX METHOD: AN EXAMPLE OF FLOODING OF TYPHOON NO.1112
}

\author{
御厨純 $^{1} \cdot$ 二瓶泰雄 ${ }^{2} \cdot$ 鈴木大樹 $^{1} \cdot$ 中山朝陽 ${ }^{3}$ \\ Jun Mikuriya, Yasuo NIHEI, Taiki SUZUKI and Tomoharu NAKAYAMA \\ 1学生員 学 (工) 東京理科大学大学院 理工学研究科土木工学専攻修士課程 \\ （干278-8510千葉県野田市山崎2641） \\ 2正会員 博（工） 東京理科大学准教授 理工学部土木工学科（同上） \\ 非会員 東京理科大学 理工学部土木工学科（同上）
}

\begin{abstract}
A discharge monitoring system with velocity measurement by two H-ADCPs and numerical simulations using DIEX method was applied to flood-discharge monitoring in a compound channnel in Edogawa River under flooding due to typhoon no.1112. In the present system, we used two H-ADCPs in which one was installed in the main channel and the other in the floodplain. The results indicate that the calculated velocity and discharge using the present method with two H-ADCPs give good agreements with the field data measured by ADCP. The relative errors of calculated discharge by the present method using two H-ADCPs are appreciably lower than that using a H-ADCP. This fact demonstrates that the present method using two H-ADCPs are useful to monitor flood discharge in a compound channel.
\end{abstract}

Key Words : discharge measurement, H-ADCP, DIEX method, compound channel,Edogawa River

\section{1. 序論}

近年の八ッ場ダム建設是非をめぐる議論を始めとして, 「ダムによらない治水」の検証が全国各地の河川で行わ れている ${ }^{1)}$. そこでは河川管理上最重要項目である「基 本高水」の検証が必要となるところもあり, このために 河川における流量観測技術の精度検証・高度化や新計測 技術の導入は極めて重要である.

流量観測の新計測技術としては ADCPが最も注目を浴 びているが 2)，ADCPによる流量観測を行うには，一般 に, 河川横断面内にて ADCPを何らかの形で移動させる 必要があり, 自動連続計測への適用には非現実的である.

一方，同じドップラー技術に基づく水平設置型超音波ド ップラー流速分布計 H-ADCP (Horizontal ADCP) は，わず か一台である高さの流速横断分布を計測でき，自動連続 計測に最適な機器の一つである ${ }^{3)}$ 。また, H-ADCP では

「線」流速データしか計測できないため, 流量算出に必 要な「面」流速データを推定するための新たな数值解析
技術として力学的内外捜法 (Dynamic Interpolation and EXtrapolation method, DIEX法) が構築されている4)，5). この H-ADCP 計測と DIEX 法による数值シミュレーショ ンを融合した流量モニタリングシステム（以下，本シス テム）はこれまでに様々な河川の流量計測に適用され， その妥当性や有効性が幅広い条件下で検証されている ${ }^{4}$ 〜8). 今後, 本システムの適用範囲を更に拡張する上では, 我が国の一般的な河道断面形である複断面河道の洪水流 量モニタリングに本システムを適用して行くことは必須 であり，その基礎的検討を江戸川で既に行っている（岩 本・二瓶 ${ }^{8}$ ，以下前報と呼ぶ）。しかしながら，前報で はH-ADCP1 台を低水路のみに設置していたが, 幅数百 $\mathrm{m}$ の複断面河道全体にわたり流速計測するのは非現実的で あり, 本システムの精度向上のためには複断面河道内に おける $\mathrm{H}-\mathrm{ADCP}$ の設置・設定条件（台数，周波数，計測 モード等）を検討することは必須である.

著者らは，本システムに基づく複断面河道流量観測の 高精度化・汎用化を目指して, 複断面河道を有する江戸 
川において, 低水路 1 台, 高水敷 1 台の計 2 台の H-ADCP を2009年に設置し, 高水敷が冠水する程度の中・大規模 出水の観測に備えていた. 紀伊半島を中心に大雨をもた らした台風 1112 号接近により, 江戸川においても中規模 出水が発生した. 本論文では, この台風 1112 号出水を例 として，2 台の H-ADCP 計測を用いる本システムによる 複断面河道の洪水流量モニタリングを行い，本システム の有効性を検討することを試みる. この出水時では，同 時に ADCP 観測 ${ }^{9}$ をを行い, 本システムの流速・流量推定 精度を検証する.ささらに，ここで得られた結果を活用し て, 擬似的に H-ADCP の設置・設定条件を変化させ，そ れらが流速・流量推定精度に及ぼす影響も検討する。

\section{2. 本流量モニタリングシステムの概要}

本流量モニタリングシステムは, 図一1に示寸ように, (1)H-ADCPによる「線」流速計測と，(2)DIEX法に基づく 「面」流速・流量算出の 2 つのサブシステムから構成さ れている $\left.{ }^{4,}, 5\right)$. サブシステム(1)の H-ADCP計測では, 上 述したように，低水路 1 台，高水敷 1 台を設置した状況 を模式的に示している。この場合，本システムでは，渇 水時から大出水時まで計測することを念頭にしているた め, 低水路に設置される H-ADCP の計測位置は, 常時冠 水する高さとする必要があり, この H-ADCP の計測範囲 は, 一般に低水路内に限定される. そのため, 高水敷上 の流速データを取得するために, 高水敷にも H-ADCP 1 台を設置する状況を想定している.この場合でも, H-ADCP からの距離が離れると超音波ビームが水面・底面に当た るため, 高水敷全体にわたり流速計測するのは難しくな るが，コスト面を考慮して，ここでは高水敷 1 台を採用 している.

一方，(2)の数值解析サブシステムでは，ある横断面を 計算対象として, 三次元ナビエ・ストークス方程式にお ける移流項や非定常項を省略し, 代わりに付加項 Fa を加 えた次の基礎式を用いる.

$$
g I+\frac{\partial}{\partial y}\left(A_{H} \frac{\partial u}{\partial y}\right)+\frac{1}{D^{2}} \frac{\partial}{\partial \sigma}\left(A_{V} \frac{\partial u}{\partial \sigma}\right)+F a=0
$$

ここで, $u$ は主流方向流速, $A_{H}$ と $A_{V}$ は水平・鉛直渦動 粘性係数, $g$ は重力加速度, $I$ は水面勾配, $D$ は水深を それぞれ表す。 サブシステム(1)よって得られた流速デ 一タを数值シミュレーションに同化する際には，この付 加項 $F a$ を介して行っており, 式 (1) を水深平均した次 式を用いている.

$$
g I+\frac{\partial}{\partial y}\left(\overline{A_{H}} \frac{\partial \bar{u}}{\partial y}\right)-\frac{C_{f}}{D} \bar{u}^{2}+F a=0
$$

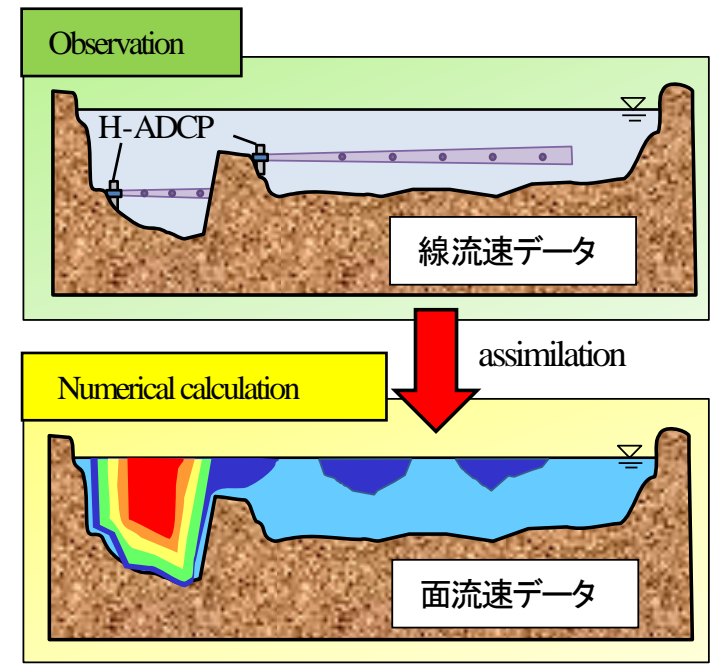

図一1＼cjkstart本流量モニタリングシステムの概要

ここで, $\overline{A_{H}}$ は水深平均水平渦動粘性係数, $C_{f}$ は底面 摩擦係数 $\left(=g n^{2} / D^{1 / 3}, n\right.$ : マニングの粗度係数) であ る. なお，付加項 $\mathrm{Fa}$ は二瓶・木水 ${ }^{4)}$ と同様に鉛直方向 に一様として与えている. なお，前報では，高水敷に繁 茂する植生群落の効果を考慮するために，式（1），(2) 中に植生抵抗項を考慮していたが，本論文ではこの項を 含んでいない．植生抵抗項中のパラメータ（植生密度） を現地植生分布に基づいて精緻に与えるのは容易ではな く, 高水敷の流速計測を行っていない前報では，その植 生パラメータをチューニングする必要があった. 一方, 高水敷にもH-ADCPが設置されている本論文では, H-ADCP データを数值解析に同化することにより, 付加項を介し て植生効果を取り込むことができるため，植生抵抗項を 含まない基礎式を用いることができ，それが前報よりも 本システムが大きく進展している部分である.

\section{3. 本システムに基づく江戸川洪水流量モニタリン グの概要}

\section{（1）現地観測の概要}

観測対象サイトは，著者らが長年流量計測を行ってい る江戸川中流部・野田（河口から $39 \mathrm{~km}$ ）であり, その平 面図と横断面図を図一2に示寸。この横断面では，堤間幅 が約 $400 \mathrm{~m}$, 低水路幅が約 $100 \mathrm{~m} ゙$ あ゙り, 高水敷は右岸側に 大きく広がっている. また，右岸側高水敷はゴルフ場と して利用されており, 樹木が点在すると共に, ヨシ群落 が存在している ${ }^{10}$. 出水前後の横断測量を行ったところ, 顕著な河床変動は観測されなかった。

この横断面において，図一2に示すように，H-ADCPを 低水路と高水敷にそれぞれ 1 台ずつ設置する. 機種とし ては，低水路にはH-ADCP600kHz，高水敷には同300kHz (共に，TeledyneRD製）である. 低水路では，既設の水 位標にH-ADCPを右岸向きに固定し(左岸側堤防天端から の横断距離 $y=46.1 \mathrm{~m}$, 高さ $z=3.41$ Y.P.m) , 高水敷では, 単 


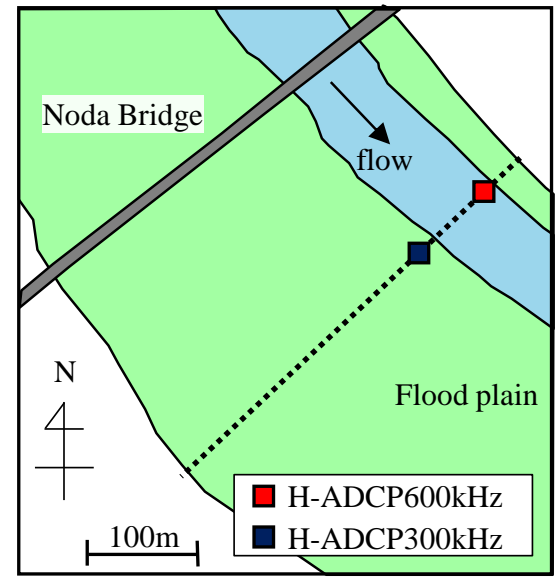

(a) 平面図

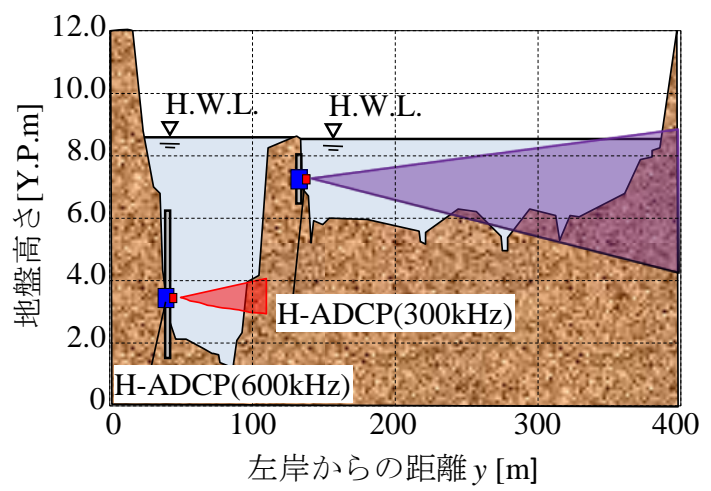

(b) 横断面図

図一2 観測サイト（江戸川野田橋）

管を組み立てた架台を設置し、それにH-ADCPを同じく右 岸向きに取り付ける ( $y=137 \mathrm{~m}, z=7.23$ Y.P.m) . 設置期間 としては，低水路では2006年6月6日から現在まで，高水 敷では 2010年7月1日から現在までである（ただし，2009 年度には高水敷にH-ADCP600kHzを設置していた）。

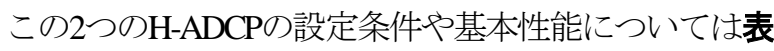
-1に示寸とおりである. 濁度増加に伴う超音波減衰効果 を減少させるため ${ }^{11)}$, 計測層厚 (横断方向の計測分解能) は低水路では $3.0 \mathrm{~m}$, 高水敷では $4.0 \mathrm{~m}$ と，層数はそれぞ れ20層，70層としている．この表に示すように，高水敷 に設置した周波数 $300 \mathrm{kHz}$ タイプのH-ADCPは, 低濁度時に は最大 $400 \mathrm{~m}$ 計測できるが，超音波ビームの広がり幅が1 度であるので, 超音波ビームが対岸に届く前に水面また は底面に当たってしまう.今回のH.W.L時の計測範囲は, 図一2に示寸ように, H-ADCPから100m程度となっている.

H-ADCPには水位計測機能は付いていないため, 流量算 定には別途水位計測を行う必要がある. そのため, 低水 路では，国交省が野田において計測している水位観測デ 一夕を用いる。一方, 予備観測結果より, 同一横断面に おける低水路と高水敷にて水位差があることが判明して いたので, 高水敷においてもH-ADCP付近において自記式 水位計（U20 Water Level Logger，Onset社）を設置し，10分 間隔で水位計測を行った。 なお，高水敷には，本論文の
表-1 H-ADCP の設定条件と基本性能

\begin{tabular}{|c|c|c|}
\hline 項目 & $600 \mathrm{kHz}$ & $300 \mathrm{kHz}$ \\
\hline 設定層数 & 20 & 70 \\
\hline 設定層厚 $[\mathrm{m}]$ & 3.0 & 4.0 \\
\hline 測定間隔[分] & 10 & 10 \\
\hline 不感帯幅 $[\mathrm{m}]$ & 3.98 & 6.17 \\
\hline \hline 最大測定範囲 $[\mathrm{m}]$ & $80 \sim 140$ & $160 \sim 400$ \\
\hline ビーム数 & 3 & 2 \\
\hline ビーム幅 $\theta_{V}\left[^{\circ}\right]$ & 1 & 1 \\
\hline ビーム発射角 $\theta_{H}\left[^{\circ}\right]$ & 25 & 10 \\
\hline 測流範囲 $[\mathrm{m} / \mathrm{s}]$ & \pm 10 & \pm 5 \\
\hline
\end{tabular}

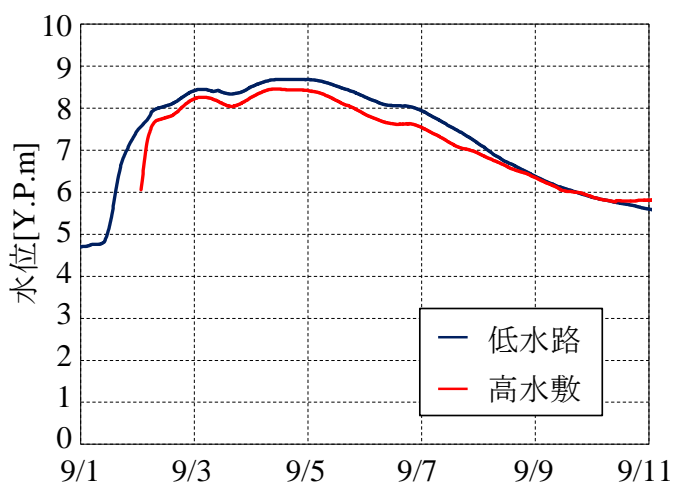

図-3 低水路と高水敷における水位の時間変化

計測横断面やその上・下流に複数の水位計測を行ってお り，この結果に関しては，別途報告する予定である.

観測期間となる台風1112号接近時における野田橋での 水位の時間変化を図一3に示寸．ここでは，前述した低水 路と高水敷の水位データを表示している.これより, H.W.L. は2011年9月4日17時に8.69Y.P.m（低水路）を記録し，2007 年台風9号以来の出水となった. また，8.0Y.P.m以上の高 水位が2日を越える洪水継続時間の長い出水であった. こ こで注目すべき点は，低水路と高水敷の水位差が洪水期 間中明確に継続し, 最大で $0.23 \mathrm{~m}$ の水位差となった点であ る. そのため，低水路と右岸側高水敷は基本的には分断 された状態となっていた.

また，検証用観測として，二種類のADCP観測を実施 している. まず，本システムの観測横断面よりも $200 \mathrm{~m} 上$ 流の野田橋において, ADCP移動観測法” を実施している. これは，高水敷が冠水した2011年9月2日〜6日の日中に合 計 25 往復観測を行っている. このデータを用いて，本シ ステムの流量推定精度を検証する. 次に, 本研究におい て新たに高水敷に設置したH-ADCP300kHzの流速計測精度 を検証するために，本システムの観測横断面の右岸側高 水敷の140～370m地点において, ADCPを鉛直下向きに固 定し, 1分間計測して, 各地点の流速鉛直分布データを取 得する.これを同年9月2日10時，14時，4日18時の計3回 にわたり実施した. 
表一2 DIEX 法における計算条件

\begin{tabular}{|l|c||c|c|}
\hline & \multirow{2}{*}{$\begin{array}{c}\text { H-ADCP } \\
\text { 台数 }\end{array}$} & 低水路 & 高水敷 \\
\hline Case1 & 1台 & 一様法 & - \\
\hline Case2 & 2台 & 一様法 & 一様法 \\
\hline Case3 & 2台 & 一様法 & 三次スプライン補間法 \\
\hline Case4 & \multicolumn{2}{|c|}{ Case2, 3で間法範囲を減少させる. } \\
\hline
\end{tabular}

\section{（2）計算条件}

DIEX法における計算条件について記述する. 計算期間 は，2011年9月2日から7日までとする. 計算格子幅は, 横 断方向に関しては, 低水路・高水敷共に $0.5 \mathrm{~m}$ とする. 計 算格子数は, 鉛直方向には 100, 横断方向には828として いる. データ同化範囲Ymaxに関しては，低水路では，基 本的には, 高濁度化による超音波減衰効果を考慮するた めに，反射強度のある闇值を設定していたが，本論文で 対象と寸る台風1112号出水では，この閾值を下回る反射 強度は観測されなかった. そのため, 流速計測精度の検 証結果より与えられ，初期に設定した $Y m a x=36 \mathrm{~m}$ とした. 高水敷におけるデータ同化範囲Ymaxに関しては, H-ADCP より発信される超音波ビームが水面または底面にあたる 位置とする. また, マニングの粗度係数nは低水路, 高水 敷それぞれ $0.035 \mathrm{~m}^{-1 / 3} \mathrm{~s}, 0.040 \mathrm{~m}^{-1 / 3} \mathrm{~s}$ とする メータについては，前報を参照されたい，

2台のH-ADCP流速データを同化データとして取り込み, それから計算される付加項 $F a$ の外挿操作としては, 「3 次スプライン補間法」 ${ }^{4)}$ と付加項を横断方向に一様とす る「一様法」 ${ }^{8)}$ が挙げられる. 今回の出水は, 横断面に おいて低水路と高水敷が完全に繋がっておらず，分断し て流れているため, 付加項の補間操作についても低水路 と高水敷について別々に行う。このことを反映し，本論 文の目的の一つであるH-ADCPの設置·設定条件と流量推 定精度の関係を見るために, 表一2に示す4ケースの計算 条件を設定する. ここでは, H-ADCPの台数と付加項の補 間法により，H-ADCP1台（低水路のみ）で一様法を用い るCase1，H-ADCP2台（低水路と高水敷）で一様法を用い るCase2, 同じく2台で補間法は低水路では一様法, 高水 敷では三次スプライン補間法を用いるCase3を設定する. またCase4では, 台数と補間法はCase2, 3 3 同じであるが, 低水路と高水敷の同化範囲を元々の範囲Y $\max の \alpha \%(\alpha$ $=10$ から 100 に設定）と短くし，計算結果に対する同化範 囲の影響を見る.

また, 水位に関しては, 図一3に示寸低水路と高水敷の 水位差を考慮して, 低水路内と高水敷（右岸側）におい て，それぞれの観測值を与える.

\section{4. 結果と考察}
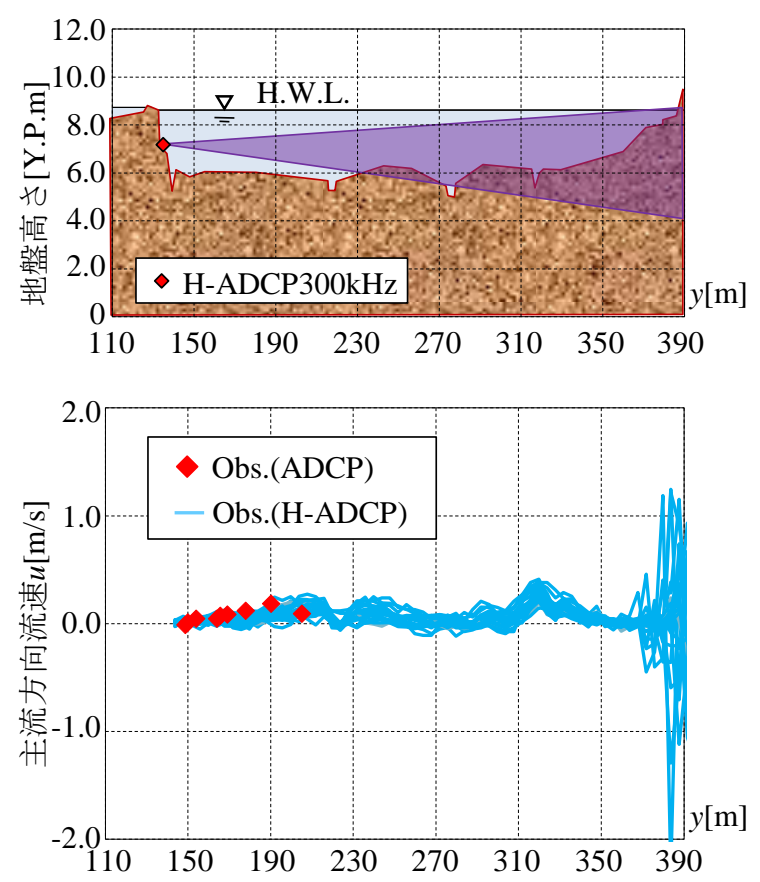

(a) 9 月 2 日 10 時（水位 : 7. 74Y.P. m)

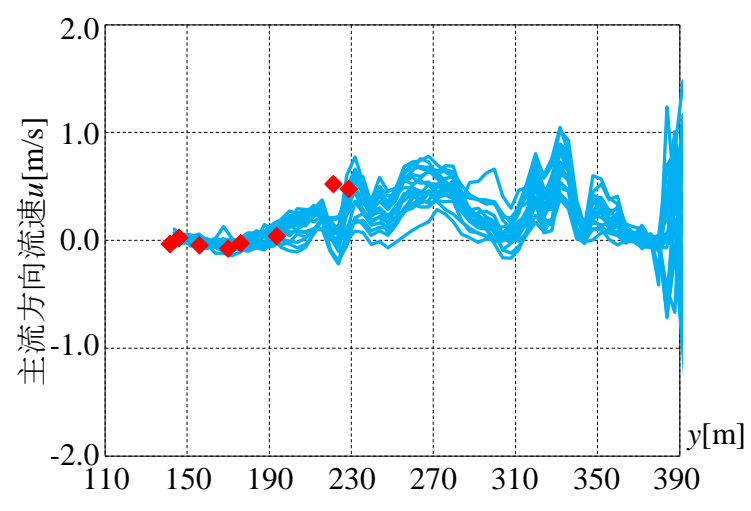

(b) 9 月 4 日 18 時（水位 : 8. 44Y.P. m)

図-4 高水敷の H-ADCP 計測高さにおける H-ADCP と $\mathrm{ADCP}$ の主流方向流速横断分布の比較

\section{（1）高水敷におけるH-ADCPの流速計測精度}

高水敷に設置されたH-ADCPの流速計測精度を調べるた めに，H-ADCPとADCPによる主流方向流速の横断分布を 図ー4に示寸．ここでは，H-ADCPの計測高さに合わせる ように，ADCP観測データを抽出している.また， 9210 時と9/4 18時の結果について, H-ADCPは対岸付近まで の計測值を，ADCPについてはデータ同化範囲（H-ADCP の超音波ビームが水面もしくは底面に当たるまでの範囲) をそれぞれ表示している. また，H-ADCPデータについて は，ADCP観測時間に合わせて3時間分の結果を図示して いる. これより, 両時刻ともに, H-ADCPの流速値は同化 範囲においてはADCP観測結果と概ね一致しており， H-ADCPによる流速計測が良好に行われていることが分か る. なお，同化範囲外では，超音波ビームが水面もしく 

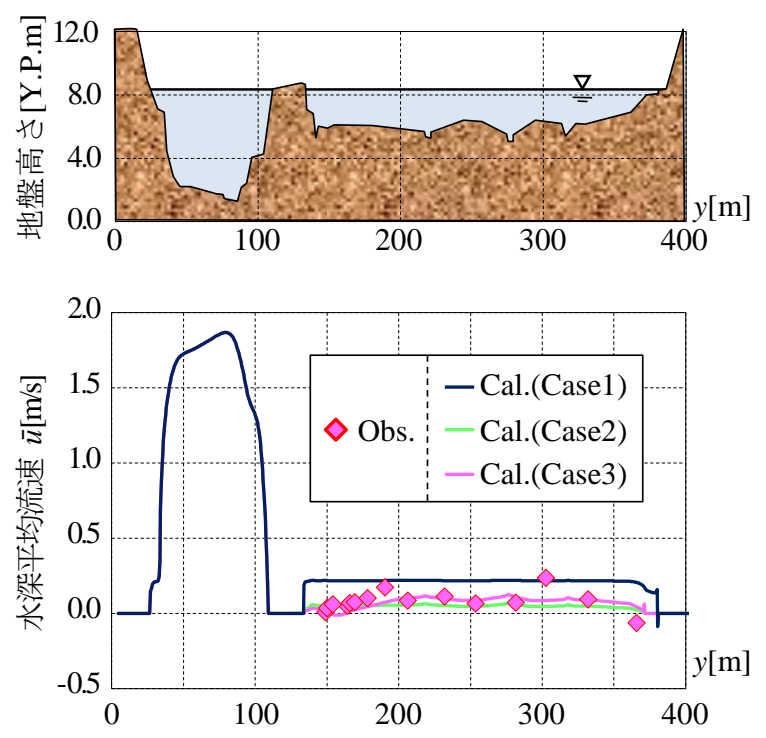

(a) 9 月 2 日 10 時

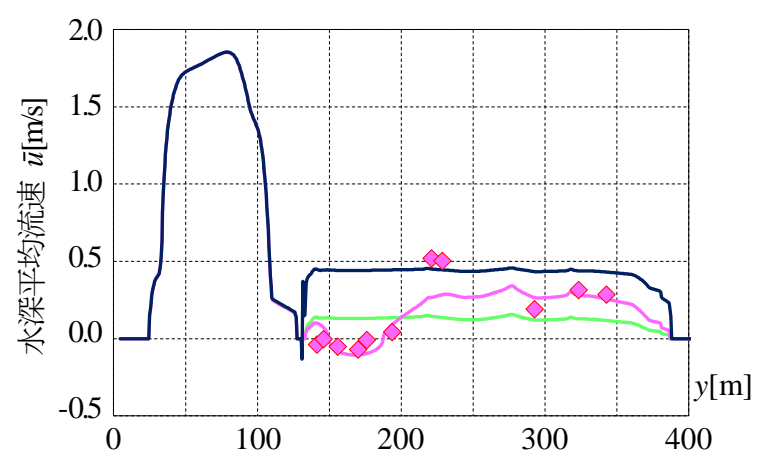

(b) 9 月 4 日 18 時

\section{図-5 水深平均流速横断分布の観測值と推定値の比較 (Case1 3)}

は底面に反射し計測範囲は不明確になるものの，対岸に 達していると考えられるy>370mを除き，H-ADCPデータ がADCP観測課結果よりも大幅にずれることなく推移し ていることは確認されており, 今後, これらの流速デー タの取り扱いについて検討する予定である.

\section{（2）流速推定精度}

2台のH-ADCPを用いた本手法による流速分布再現性向 上効果を確認するために, 水深平均流速の横断分布に関 するADCPによる観測值と本手法による推定值を比較し たものを図一5に示す。ここでの推定結果は，H-ADCPを 低水路に1台のみ用いた場合（Case1）と計2台用いた場合

(Case2，3）について，図一4と同じ時刻の結果が表示さ れている. また，低水路では，どの計算結果についても 同じになることに注意されたい. これより, H-ADCP 1 台 のみの場合 (Casel) では, 高水敷における流速が過大評 価されており，観測值とのずれが最も大きい，それに対 して，H-ADCP2台を用いる場合には，高水敷での流速レ

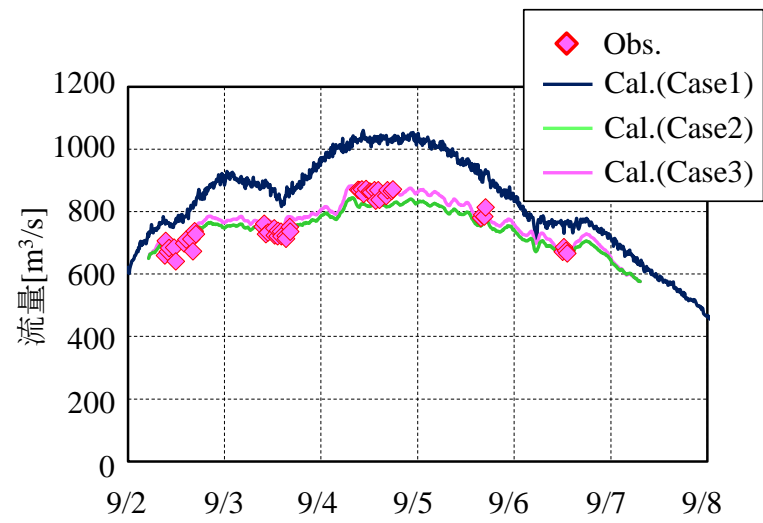

図一6 流量の時系列変化に関する観則値と推定値の比較 (Case1 3)

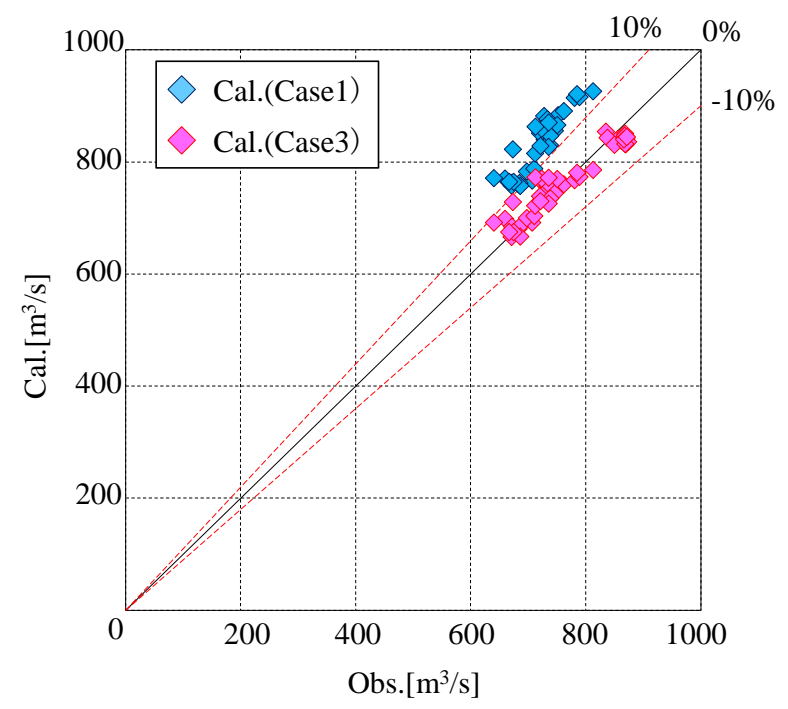

図-7 流量に関する観測值と推定値の相関図（図中の実線， 点線は推定結果の誤差 $0, \pm 10 \%$ を示す, Casel と 3 )

ベルは観測值と一致するものの，その精度は付加項に対 して三次スプライン補間法を用いるCase3の方が高くなっ ており，その差は流速分布の凹凸が大きい $9 / 4$ 18時の結 果で顕著である，H-ADCPを2台用いることにより，流速 推定精度が明確に向上寸ると共に, 付加項の補間方法が この精度に関連していることが示された.

\section{（3）流量推定精度}

本手法に流量推定精度の検証をするために, 対象出水 時における流量の時系列変化を図一6に示寸.ここでも図 -5 と同様に, 観測值とCase1〜3の推定值を図示している. これより，H-ADCP1台のみ用いたCase1では，流量を過大 に評価しており, 図一5の流速推定值と符合した結果とな っている. 一方, H-ADCP2台したCase2と3では概ねADCP による観測值と一致しており，三次スプライン補間法を 用いたCase3の方がやや精度が高い.

より詳細に流量推定精度を検証するため，流量の観測 值と計算值の相関図を図ー7に示す.ここでは推定值とし ては，Case2と3の違いがそれほど明確でなかったので， Case2は省略している. これより, H-ADCP1台のCase1の推 


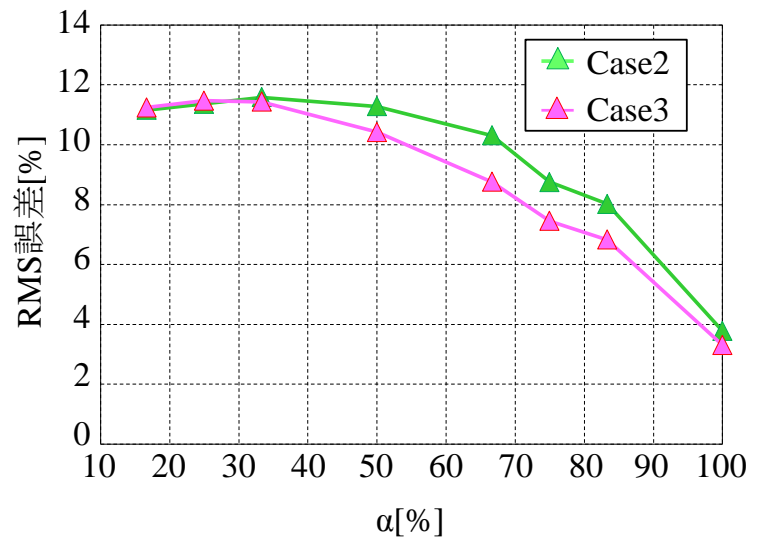

図ー8 様々な同化範囲の減少率 $\alpha$ における流量推定誤差 (Case4)

定結果は10\%を超える誤差が多く見られるのに対して, H-ADCP2台のCase3では概ね誤差は土10\%以内になってい る. また，観測值と推定值の間の誤差のRMS值をCasel〜 3において算出した結果, Case1, 2, 3ではそれぞれ17.1\%, 3.8\%，3.3\%となり，H-ADCP2台を用いたCase2，3の精度 が極めて良好である. 以上より，H-ADCPを低水路・高水 敷 1 台ずつ設置することにより, 複断面河道の流量モ二 タリングを高精度でかつ汎用性高く実施可能であること が明らかとなった。

\section{（4）同化範囲が流量推定精度に及ぼす影響}

上記のように，本システムでは，H-ADCPを2台用いる ことにより, 流速・流量推定精度が良好であることが示 された.このような精度は同化範囲 (H-ADCPの計測範囲) に大きく影響を受けている可能性があるため, Case4によ り得られた様々な同化範囲における流量推定誤差のRMS 值を図一8に示す。ここでは, Case2と3の結果を表示して おり， $\alpha=100 \%$ はCase2，3そのものの結果となる．これ より, 同化範囲が減少すると, 誤差值は大きくなり, 最 大で11.6\%に達するが, H-ADCP1台のCase1の誤差 (17.1\%) と比べると十分小さく，2台のH-ADCP計測の有效性が裏 付けられたことになる. また, その誤差の増加量は三次 スプライン補間法を用いるCase3の方が小さい.

\section{5. 結論}

本研究では低水路，高水敷にそれぞれ一台ずつ，計2 台のH-ADCP計測とDIEX法に基づいて複断面河道の洪水 流量モニタリングの精度向上を図ることを試みた. 本シ ステムの適用性を検証するために, 台風1112号による中 規模出水時データを基として従来までに行われていた低 水路 1 台での推定流量精度と比較することで検証を行っ た。そ結果，本イベントにおいて2台のH-ADCPを用い
ることで明らかな流量推定精度の向上が確認され，流量 推定誤差のRMS值は3\%程度となった. 以上より, H-ADCP を低水路・高水敷 1 台ずつ設置することにより，複断面 河道の流量モニタリングを高精度に実施可能であること が明らかとなった。

今後も2台のH-ADCPを用いた観測を継続し，水面・底 面での超音波ビーム反射後の流速值の精度検証やその計 測位置が明らかになれば更なる精度向上が望める.また,

H-ADCPの更なる活用法の検討を今後行う必要がある.さ らに, 付加項の内外挿方法により流速・流量推定精度が 異なることから，この内外挿方法については今後も精查 する必要がある.

謝辞 : 現地観測に際しては，国土交通省関東地方整備局 江戸川河川事務所には様々なご協力を頂いた．また，大 変な観測作業には, 東京理科大学理工学部土木工学科水 理研究室学生の惜しみないご協力のおかげである.ここ に感謝の意を表します。

\section{参考文献}

1) http://www.mlit.go.jp/river/shinngikai_blog/tisuinoarikata/220927arikatap df

2) Gordon, R. L.: Acoustic measurement of river discharge, J. Hydraulic Engineering, Vol.115, No.7, pp.925-936, 1989.

3) 岡田将治, 森彰彦, 海野修司, 昆敏之, 山田正 : 鶴見川感 潮域における H-ADCPを用いた流量観測, 河川技術論文集, Vol.11, pp.243-248, 2005.

4) 二瓶泰雄，木水啓 : H-ADCP 観測と河川流計算を融合した 新しい河川流量モニタリングシステムの構築，土木学会論 文集 B，Vol.64，No.4，pp.295-310，2007.

5) Nihei, Y. and A. Kimizu: A new monitoring system for river discharge with H-ADCP measurements and river-flow simulation, Water Resources Research, Vol.44, W00D20, doi:10.1029/2008WR006970, 2008.

6) 木水啓，二瓶泰雄 : H-ADCP と DIEX 法を用いた河川流量 計測法の洪水流観測一の適用，水工学論文集，Vol.51， pp.1057-1062, 2007.

7) 原田靖生，二瓶泰雄，北山秀飛，高崎忠勝：H-ADCP 計測 と数值計算に基づく感潮域の河川流量モニタリング〜隅田 川を例として〜, 水工学論文集, Vol.52, pp.943-948, 2008.

8) 岩本演崇, 二瓶泰雄 : H-ADCP 計測と河川流シミュレーシ ヨンに基づく複断面河道の洪水流量モニタリング, 水工学 論文集，Vol.53，pp.1009-1014，2009.

9) 二瓶泰雄, 色川有, 井出恭平, 高村智之 : 超音波ドップラ 一流速分布計を用いた河川流量計測法に関する検討，土木 学会論文集 B, Vol.64, No.2, pp.99-114, 2008.

10) 加茂川優紀, 二瓶泰雄 : 出水時における河川内草本類の破 壊条件に関する基礎的検討，河川技術論文集，Vol.17， pp.239-244, 2011.

11) 二瓶泰雄, 岩本演崇, 谷古宇洋介 : H-ADCP の有効計測範 囲の検討，水工学論文集，Vol.54，pp.1099-1104，2010.

(2011.9. 30 受付) 